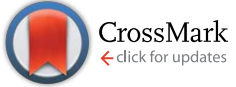

Cite this: Chem. Sci., 2017, 8, 1601

Received 12th October 2016 Accepted 4th November 2016

DOI: $10.1039 /$ c6sc04504a

www.rsc.org/chemicalscience

\title{
Metal-free $\mathrm{O}-\mathrm{H} / \mathrm{C}-\mathrm{H}$ difunctionalization of phenols by 0 -hydroxyarylsulfonium salts in water $\uparrow$
}

\author{
Dengfeng Chen, Qingyuan Feng, Yunqin Yang, Xu-Min Cai, Fei Wang \\ and Shenlin Huang*
}

An environmentally benign method for $\mathrm{C}-\mathrm{H} / \mathrm{O}-\mathrm{H}$ difunctionalization of phenols with sulfoxides under mild conditions has been developed. The reaction process is mediated by an electrophilic aromatic substitution and subsequent selective aryl or alkyl migration, involving $\mathrm{C}-\mathrm{S}$ and $\mathrm{C}-\mathrm{O}$ bond formations with broad substrate scope.

\section{Introduction}

Carbon-heteroatom bond forming reactions are one of the most important tools used in pharmaceutical chemistry, medicinal chemistry, and material sciences. ${ }^{1}$ In particular, transition metal catalyzed $\mathrm{C}-\mathrm{O}$ or $\mathrm{C}-\mathrm{S}$ cross-couplings, ${ }^{2}$ have

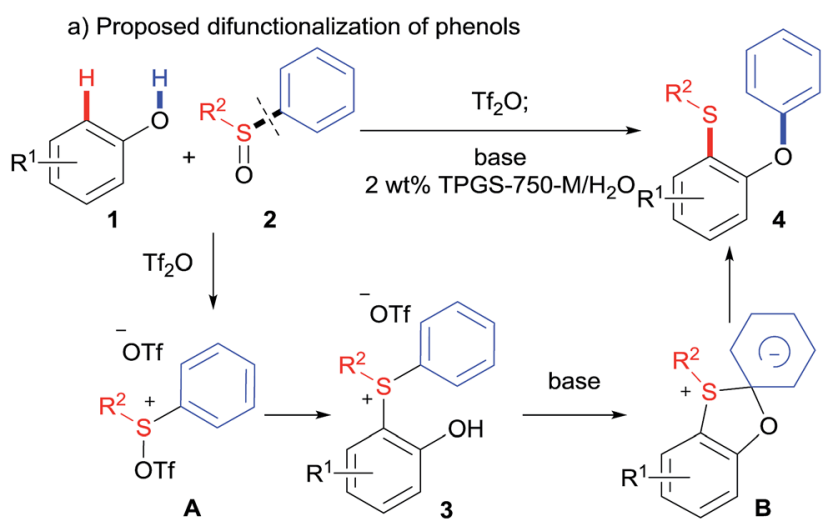

b) Selected important target molecules<smiles>COc1ccc2ccccc2c1[SH](C)(=O)c1cccc2ccn(-c3ccccc3)c12</smiles><smiles>COc1ccc2ccc(C(N)=NC(=O)OS(C)(=O)=O)cc2c1Sc1ccccc1</smiles>

urokinase inhibitor (8) been widely used to construct important families of target molecules, aryl ethers, sulfides and sulfoxides. ${ }^{3}$ Traditionally, these reactions are carried out in organic solvents (e.g., THF, $\mathrm{CH}_{3} \mathrm{CN}$, DMSO, and DMF), which may cause potential health, safety, and waste disposal issues. ${ }^{4}$ Therefore, transition-metalfree $\mathrm{C}-\mathrm{O}$ and $\mathrm{C}-\mathrm{S}$ coupling reactions $\mathrm{s}^{5}$ under greener conditions are desirable, especially in the pharmaceutical industry. ${ }^{6}$ Herein, we report our efforts toward a novel environmentally benign $\mathrm{O}-\mathrm{H} / \mathrm{C}-\mathrm{H}$ difunctionalization of phenols by $o$-hydroxyarylsulfonium salts in water (Scheme 1).

Our reaction design is detailed in Scheme 1. It is reasonable to hypothesize that sulfoxides 2 may be activated using a sulfonylating agent like trifluoromethanesulfonic anhydride $\left(\mathrm{Tf}_{2} \mathrm{O}\right)$, inspired by the Pummerer reaction. ${ }^{7}$ The activated sulfoxide $\mathbf{A}$ could be attacked by phenols $\mathbf{1}$ at sulfur, giving rise to $o$-hydroxyarylsulfonium intermediates 3 . Such intermediates might then undergo a Smiles-like rearrangement, ${ }^{8}$ thus affording versatile products $o$-(phenoxy)aryl sulfides, 4 , which could be readily converted to many important ligands ${ }^{9}$ and biologically active molecules ${ }^{10}$ (Scheme 1b). However, the following challenges in this strategy were anticipated: (1) the activated sulfoxide can be attacked by the phenolic hydroxyl group at the cationic sulfur, according to previous studies; ${ }^{11}$ (2) it may require one electron-withdrawing group (e.g., $\mathrm{NO}_{2}$ ) to activate the migration of the aromatic ring in the Smiles rearrangement; (3) such rearrangement of sulfonium salts has been seldom reported. ${ }^{12}$

\section{Results and discussion}

Our initial investigation began with 2-naphthol 1a and diphenyl sulfoxide $2 \mathrm{a}$ in the presence of $\mathrm{Tf}_{2} \mathrm{O}$ in acetonitrile at $0{ }^{\circ} \mathrm{C}$. To our delight, the new sulfonium salt 3a was isolated in $95 \%$ yield. Somewhat surprisingly, this type of $o$-hydroxyarylsulfonium salt has never been prepared by this electrophilic aromatic substitution approach. The efficiency of this process was briefly examined with various phenols and sulfoxides, as shown in Table 1. Naphthols with electron-withdrawing substituents (3b-3e)
College of Chemical Engineering, Jiangsu Key Lab of Biomass-Based Green Fuels and Chemicals, Nanjing Forestry University, Nanjing, 210037, P. R. China. E-mail: shuang@nju.edu.cn

$\dagger$ Electronic supplementary information (ESI) available. CCDC 1502491, 1502489 and 1502490. For ESI and crystallographic data in CIF or other electronic format see DOI: $10.1039 / \mathrm{c} 6 \mathrm{sc} 04504 \mathrm{a}$ 
Table 1 Preparation of o-hydroxyarylsulfonium salts $3^{a}$
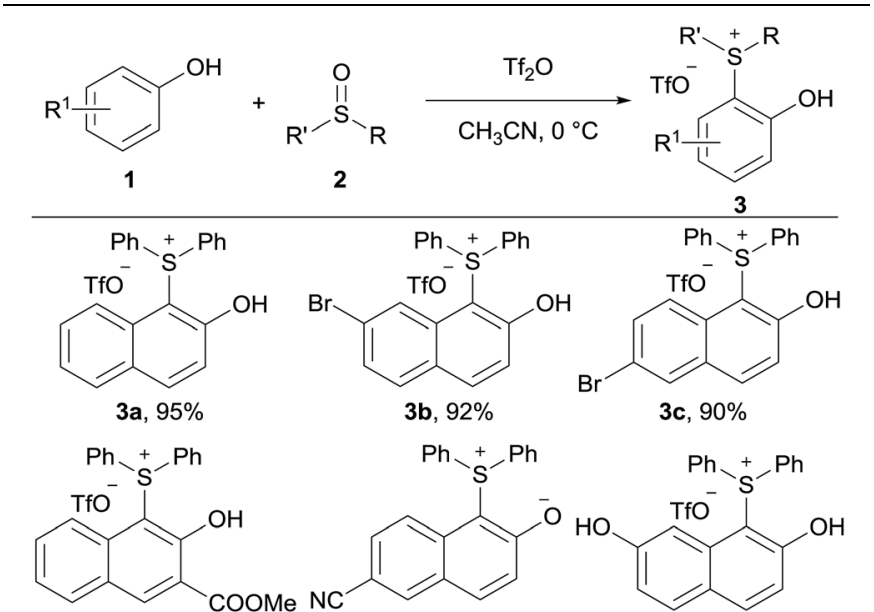

$\mathrm{Ph}+\mathrm{Ph}^{+}$ 3d, $87 \%$ 3e, $90 \%$<smiles>[B]c1ccc([S+](c2ccc(C)cc2)c2c([O-])ccc3ccccc23)cc1</smiles>

3g, $90 \%$<smiles>C[Si](c1ccccc1)c1c(O)ccc2ccccc12</smiles>
$3 \mathrm{~h}, 93 \%$<smiles>CCC[Se](C)c1c(O)ccc2ccccc12</smiles>

3j, $95 \%$

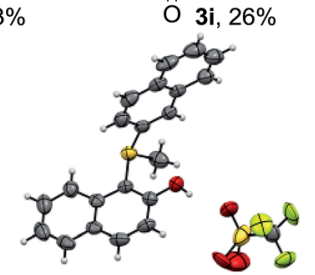

3j (X-ray structure)
${ }^{a}$ Reaction conditions: phenol $1(0.2 \mathrm{mmol})$, sulfoxide $2(0.22 \mathrm{mmol})$, $\mathrm{Tf}_{2} \mathrm{O}(0.24 \mathrm{mmol}), \mathrm{MeCN}(0.1 \mathrm{M})$ at $0{ }^{\circ} \mathrm{C}$ for $3 \mathrm{~h}$.

worked equally well as those with electron-donating groups (3f). In addition, both diaryl sulfoxides and alkyl aryl sulfoxides led to the corresponding products in excellent yields $(\mathbf{3 g}, \mathbf{3 h}$, and $\mathbf{3 \mathbf { j }})$. Interestingly, $\mathbf{3 e}$ and $\mathbf{3 g}$ were isolated as zwitterions. Unfortunately, though not entirely unexpected, a poor yield was observed when 4-hydroxyacetophenone was treated with diphenyl sulfoxide $2 \mathrm{a}$.

With isolated salt 3a in hand, we sought to determine its reactivity in a Smiles-like rearrangement, as a stepwise and general methodology to $o$-(phenoxy)naphthyl sulfide 4 aa (Table 2). We first explored the choice of base under aqueous micellar conditions $\mathrm{s}^{13}$ at $70^{\circ} \mathrm{C}$ (entries 1-3), utilizing TPGS-750$\mathrm{M}$, a "benign-by-design" surfactant developed by Lipshutz. ${ }^{14}$ To our delight, in this medium, $\mathrm{K}_{3} \mathrm{PO}_{4}$ was identified to be the most effective base for this rearrangement (entry 4). Lowering the reaction temperature led to incomplete conversion and, therefore, a decreased yield (entry 5). No increase in yield was observed at higher temperature (entry 6). Other surfactants including Triton X-100 and SDS were screened, as were organic solvents $\left(\mathrm{CH}_{3} \mathrm{CN}\right.$, THF, and DMF). All afforded inferior results
Table 2 Optimization of the reaction conditions ${ }^{a}$

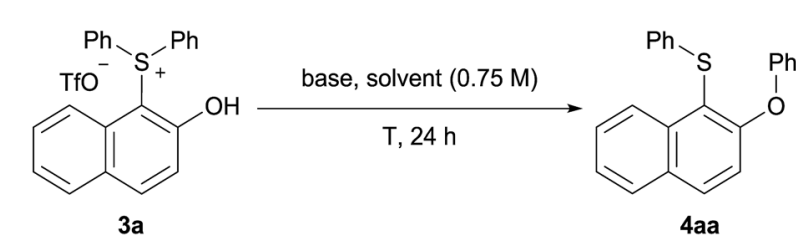

\begin{tabular}{|c|c|c|c|c|}
\hline Entry & Base & Solvent & $T$ & Yield $^{b}$ \\
\hline 1 & $\mathrm{NaHCO}_{3}$ & TPGS-750-M/ $\mathrm{H}_{2} \mathrm{O}^{c}$ & $70{ }^{\circ} \mathrm{C}$ & $78 \%$ \\
\hline 2 & $\mathrm{CsF}$ & TPGS-750-M/ $\mathrm{H}_{2} \mathrm{O}^{c}$ & $70{ }^{\circ} \mathrm{C}$ & $60 \%$ \\
\hline 3 & $\mathrm{Et}_{3} \mathrm{~N}$ & TPGS-750-M/ $\mathrm{H}_{2} \mathrm{O}^{c}$ & $70{ }^{\circ} \mathrm{C}$ & $88 \%$ \\
\hline 4 & $\mathrm{~K}_{3} \mathrm{PO}_{4}$ & TPGS-750-M/ $\mathrm{H}_{2} \mathrm{O}^{c}$ & $70{ }^{\circ} \mathrm{C}$ & $93 \%$ \\
\hline 5 & $\mathrm{~K}_{3} \mathrm{PO}_{4}$ & TPGS-750-M/ $\mathrm{H}_{2} \mathrm{O}^{c}$ & $60{ }^{\circ} \mathrm{C}$ & $70 \%$ \\
\hline 6 & $\mathrm{~K}_{3} \mathrm{PO}_{4}$ & TPGS-750-M/ $\mathrm{H}_{2} \mathrm{O}^{c}$ & $80{ }^{\circ} \mathrm{C}$ & $90 \%$ \\
\hline 7 & $\mathrm{~K}_{3} \mathrm{PO}_{4}$ & Triton $\mathrm{X}-100 / \mathrm{H}_{2} \mathrm{O}^{c}$ & $70{ }^{\circ} \mathrm{C}$ & $76 \%$ \\
\hline 8 & $\mathrm{~K}_{3} \mathrm{PO}_{4}$ & $\mathrm{SDS} / \mathrm{H}_{2} \mathrm{O}$ & $70{ }^{\circ} \mathrm{C}$ & $58 \%$ \\
\hline 9 & $\mathrm{~K}_{3} \mathrm{PO}_{4}$ & $\mathrm{CH}_{3} \mathrm{CN}$ & $70{ }^{\circ} \mathrm{C}$ & $75 \%$ \\
\hline 10 & $\mathrm{~K}_{3} \mathrm{PO}_{4}$ & THF & $70{ }^{\circ} \mathrm{C}$ & $78 \%$ \\
\hline 11 & $\mathrm{~K}_{3} \mathrm{PO}_{4}$ & DMF & $70{ }^{\circ} \mathrm{C}$ & $86 \%$ \\
\hline 12 & $\mathrm{~K}_{3} \mathrm{PO}_{4}$ & $\mathrm{H}_{2} \mathrm{O}$ & $70{ }^{\circ} \mathrm{C}$ & $70 \%$ \\
\hline
\end{tabular}

${ }^{a}$ Conditions: $3 \mathrm{a}(0.375 \mathrm{mmol})$, base $(1.125 \mathrm{mmol})$, solvent $(0.75 \mathrm{M})$ for 24 h. ${ }^{b}$ Yields were determined by HPLC analysis with nitrobenzene as an internal standard. ${ }^{c}$ Using 2 wt $\%$ surfactant in water. SDS = sodium dodecyl sulfate.

(entries 7-11). A control reaction "on water" (i.e., in the absence of TPGS-750-M) was conducted and a significantly lower yield was observed (entry 12), confirming the importance of micellar catalysis in facilitating this transformation in aqueous media.

At this stage, we sought to develop a one-pot sequence. Unfortunately, synthesis of the sulfonium salts either in aqueous media or under solvent-free conditions was low yielding. Hence, sulfonium salts were prepared in situ and used directly for the rearrangement without chromatography. Gratifyingly, the desired sulfide 4 aa was produced in $86 \%$ yield from the reaction of 2-naphthol 1a and diphenyl sulfoxide 2a (Table 3).

With the optimized conditions in hand, we proceeded to explore the substrate scope of phenols $\mathbf{1}$, as shown in Table 3 . Naphthols with different substituents proceeded smoothly under the standard reaction conditions, leading to products in good to high yields (4aa-4fa). Importantly, these products (4ba4ea) bearing $\mathrm{Br}$ and $\mathrm{CN}$ substituents could be potentially further functionalized. Unfortunately, naphthol $\mathbf{1 g}$ with an amide functional group gave the corresponding product 4ga in only $15 \%$ yield. Besides naphthols, the substrate scope was further expanded to phenol derivatives. Phenols $\mathbf{1 h}-\mathbf{1 j}$ containing electron-donating groups reacted smoothly with sulfoxides $\mathbf{2 a}$ and $2 \mathbf{b}$ generating the corresponding sulfides $\mathbf{4 h a}-\mathbf{4 j a}$ and $\mathbf{4 i b}$ (X-ray) in good yields. Phenols bearing electron-withdrawing groups showed lower reactivity, leading to products $\mathbf{4 k b}-\mathbf{4 m b}$ in moderate yields. Interestingly, for $p$-unsubstituted phenols $\mathbf{1} \mathbf{j}$ and $\mathbf{1 1}$, the desired products $\mathbf{4 j a}$ and $\mathbf{4 l b}$ were obtained selectively. 
Table 3 Scope of phenols ${ }^{a, b}$

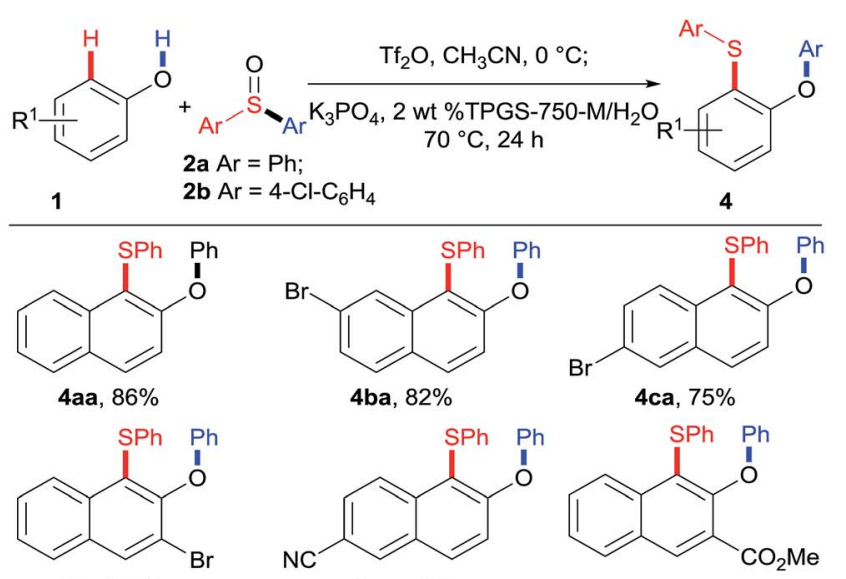<smiles>[15NH2]c1c(Oc2ccccc2)c(C(=O)Nc2ccc3ccccc3c2)cc2ccccc12</smiles>

4ga, $15 \%$<smiles>Fc1ccc(Oc2ccc(Cl)cc2)c(Sc2ccc(Cl)cc2)c1</smiles>

ha, $60 \%$

$4 \mathrm{fa}, 50 \%^{\mathrm{c}}$<smiles>Cc1cc(C)c(Sc2ccccc2)c(Oc2ccccc2)c1</smiles>

$4 \mathbf{k b}, 35 \%$<smiles>Cc1cc([SbH])c(Oc2ccccc2)cc1C</smiles><smiles>Cc1cc(Oc2ccccc2)c([SbH])c(C)c1Br</smiles>

4ia, $76 \%$<smiles>Clc1ccc(Oc2cc(Cl)cc(Cl)c2Sc2ccc(I)cc2)cc1</smiles>

$4 \mathrm{ja}, 68 \%$<smiles>Clc1ccc(Oc2ccc(Br)cc2Sc2ccc(Cl)cc2)cc1</smiles>

$4 \mathrm{mb}, 33 \%$

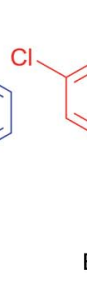

4ib, $77 \%$<smiles>CCCOc1ccc(Cl)cc1</smiles>

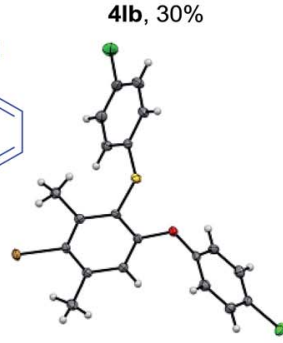

4ib (X-ray structure)
${ }^{a}$ Conditions: 1 (0.2 mmol), $2(0.22 \mathrm{mmol}), \mathrm{Tf}_{2} \mathrm{O}(0.24 \mathrm{mmol}), \mathrm{MeCN}(0.1$ $\mathrm{M})$ at $0{ }^{\circ} \mathrm{C}$ for $3 \mathrm{~h} ; \mathrm{K}_{3} \mathrm{PO}_{4}(0.88 \mathrm{mmol}), 2 \mathrm{wt} \%$ TPGS-750-M/ $\mathrm{H}_{2} \mathrm{O}(0.75 \mathrm{M})$ at $70{ }^{\circ} \mathrm{C}$ for $24 \mathrm{~h} .{ }^{b}$ Isolated yields from phenol 1. ${ }^{c}$ Hydrolysis product (carboxylic acid) was also isolated in $34 \%$ yield.

The scope of sulfoxides was then evaluated in reactions with 2-naphthol 1a (Table 4). Adducts $4 \mathbf{a b}$ and 4ac were obtained in good yields from symmetrical diaryl sulfoxides $\mathbf{2 b}$ and $2 \mathbf{c}$ with different electronic properties. Furthermore, unsymmetrical diaryl sulfoxides $\mathbf{2 d - 2 h}$ were also investigated. Remarkably, the use of sulfoxide $\mathbf{2 d}$, simultaneously bearing $p$-tolyl and phenyl residues resulted in phenyl-migrated product 4ad, while the $p$-tolyl-migrated isomer was not detected. A similar trend was observed for sulfoxides $\mathbf{2} \mathbf{e}-\mathbf{2 h}$, and the more electron-deficient aryl groups were selectively migrated delivering the corresponding sulfides 4ae-4ah. These results suggest that the
Table 4 Scope of sulfoxides ${ }^{a, b}$

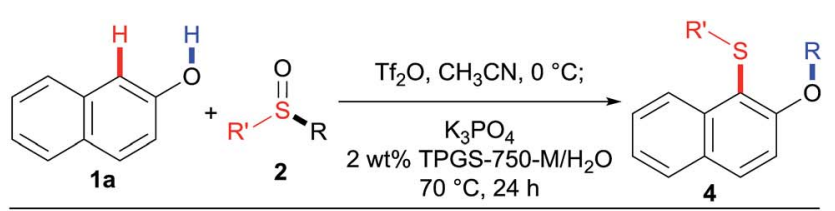<smiles>Clc1ccc(Oc2ccc3ccccc3c2Sc2ccc(Cl)cc2)cc1</smiles>

4ab, $73 \%$<smiles>[R]c1ccc(Oc2ccc3ccccc3c2Sc2ccc(C)cc2)cc1</smiles>

4ae, $\mathrm{R}=\mathrm{NO}_{2}, 65 \%$ 4af, $\mathrm{R}=\mathrm{CF}_{3}, 82 \%$ 4ag, $\mathrm{R}=\mathrm{Cl}, 60 \%$<smiles>CCOc1ccc2ccccc2c1Sc1ccccc1</smiles>

4aj, $85 \%$<smiles>COc1ccc2ccccc2c1Sc1ccc2ccccc2c1</smiles>

4am, $88 \%$<smiles>COc1ccc2ccccc2c1Sc1ccccc1Br</smiles>

4ap, 62\%<smiles>Cc1ccc(Oc2ccc3ccccc3c2Sc2ccc(C)cc2)cc1</smiles>

4ac, $68 \%$<smiles>Cc1ccc(Sc2c(Oc3ccccc3)ccc3ccccc23)cc1</smiles>

4ad, $72 \%$

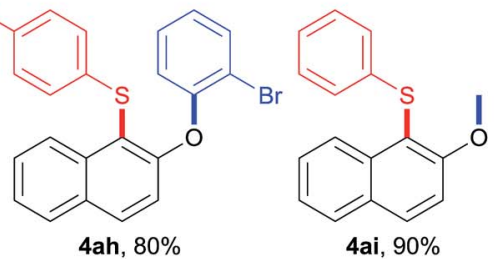

$4 \mathrm{ah}, 80 \%$

4ai, $90 \%$<smiles>CCCCCCOc1ccc2ccccc2c1Sc1ccc(C)cc1</smiles><smiles>c1ccc(COc2ccc3ccccc3c2Sc2ccccc2)cc1</smiles>

$\mathrm{Br}$<smiles>[14CH3]</smiles><smiles>COc1ccc2ccccc2c1Sc1ccc(F)cc1</smiles>

4an, 69\%<smiles>COc1ccc2ccccc2c1Sc1ccc(Cl)cc1</smiles>

4aq, $77 \%$<smiles>COc1ccc2ccccc2c1Sc1cccc([18O])c1</smiles>

4ao, $84 \%$<smiles>CSc1c(Oc2ccc(C#N)cc2)ccc2ccccc12</smiles>

4ar, $70 \%$
${ }^{a}$ See Table 3 for conditions. ${ }^{b}$ Isolated yields from phenol 1a.

rearrangement takes place by ipso-attack of a negatively charged oxygen atom onto the more electron-deficient aryl group.

Besides diaryl sulfoxides, alkyl aryl sulfoxides also participated in this transformation, further expanding the range of participating substrates. Increasing the length of the alkyl chain slightly decreased the reaction efficiency, as demonstrated by products 4ai-4ak. In addition, benzyl phenyl sulfoxide $2 \mathbf{l}$ is also a competent reaction partner, providing $\mathbf{4 a l}$ in $78 \%$ yield. Moreover, the aryl group could also be modified with different 
a) Difunctionalization of estrone<smiles>CC1CC[C@]2(C)C(=O)CC[C@H]2c2ccc(O)cc2CC[C@@H]1C</smiles><smiles>[R]Oc1cc2c(cc1S[R])[C@@]1(C)CC[C@H]2[C@H]2CCC(=O)[C@@]2(C)CC1</smiles>

4ni: $R^{1}=P h, R^{2}=M e, 68 \%$ 4nb: $\mathrm{R}^{1}=\mathrm{R}^{2}=4-\mathrm{Cl}-\mathrm{C}_{6} \mathrm{H}_{4}, 68 \%$

b) Synthesis of urokinase inhibitor 8<smiles>COc1cc([GeH2])c2ccc(C#N)cc2c1-c1ccccc1</smiles>

Scheme 2 Application in late-stage construction and scaffold construction.

electronic properties, and the reactions furnished the corresponding sulfides in good to high yields (4ak and 4am-4ar). Importantly, there was no significant effect of substituents in the para, meta, or ortho positions. For example, $p$-bromophenyl methyl sulfoxide (2n), $m$-bromophenyl methyl sulfoxide (2o), and $o$-bromophenyl methyl sulfoxide (2p) all reacted uneventfully and gave methyl-migrated sulfides 4an-4ap in useful yields. Notably, $p$-cyanophenyl methyl sulfoxide (2r) afforded cyanophenyl-migrated product 4ar exclusively, whereas aryl methyl sulfoxides $\mathbf{2 m - 2 q}$ all provided methyl-migrated products 4am-4aq. These results suggest that stronger electronwithdrawing groups on the aryl moiety can suppress alkyl migration, leading to aryl migration instead.

To further explore the applicability of this approach, we tested this new transformation on estrone 1n containing a complex architecture. Accordingly, difunctionalization of estrone proceeded smoothly, affording 4 ni or $4 \mathbf{n b}$ in $68 \%$ yield (Scheme 2a), demonstrating the mild and selective nature of this overall transformation. In addition, a formal synthesis of urokinase inhibitor $\mathbf{8}$ was accomplished efficiently as shown in Scheme $2 b$.

We next sought to prepare sulfoxides and sulfones in one-pot (Scheme 3). Starting from 2-naphthol 1a and diphenyl sulfoxide 2a, sulfonium salt formation and then rearrangement in water gave sulfide 4aa. Without isolation, the resulting sulfide could then be oxidized to sulfoxide 5aa and sulfone 6aa in good overall yields, respectively (Scheme 3a). Sulfone $6 \mathbf{e g}$ was also obtained in high yield under similar reaction conditions. The selectivity of the Smiles-like rearrangement was unambiguously confirmed by single crystal X-ray analysis of $6 \mathbf{e g}$ (Scheme $3 \mathrm{~b}$ ).

To understand whether the rearrangement step is intramolecular or intermolecular, a crossover reaction of naphthol 1a with diaryl sulfoxides $\mathbf{2 b}$ and $\mathbf{2 c}$ was conducted under the standard reaction conditions (Scheme 4). It was found that no cross-product was detected, which suggests that this aryl migration is intramolecular. Furthermore, $\mathbf{4 a b}$ was formed in $78 \%$ yield while 4 ac was isolated in only $39 \%$ yield, indicating that sulfoxide $\mathbf{2 b}$ was more reactive than sulfoxide $\mathbf{2 c}$.
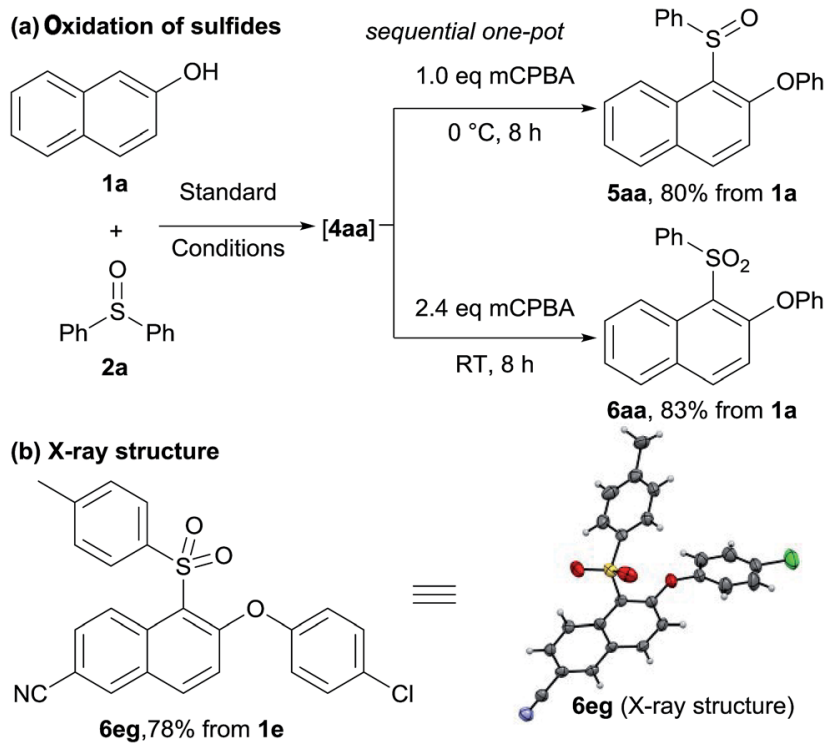

Scheme 3 Oxidation of the products in water.

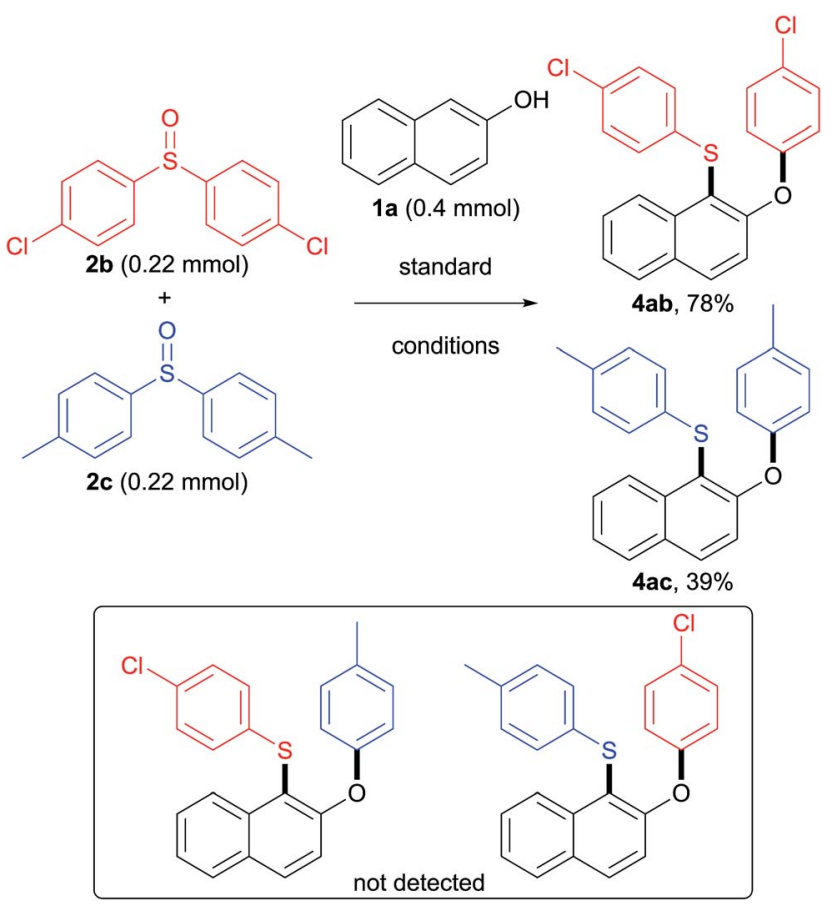

Scheme 4 Application in late-stage construction and scaffold construction.

Lastly, E Factors ${ }^{4 d, 15}$ were calculated for the rearrangement under aqueous micellar conditions, to assess the level of waste generation. Initially, an E Factor of only 4 was obtained based on organic solvent used, as illustrated in Table 5. An E Factor of only 8.6, was realized even with water included in the calculation. Moreover, the aqueous medium containing TPGS-750-M can be recycled to generate a different sulfide 4 am or $4 \mathbf{b a}$ efficiently. Since no additional water needs to be used in each cycle, the associated E Factors dropped significantly. 
Table 5 E Factors and Recycling Study ${ }^{a, b}$

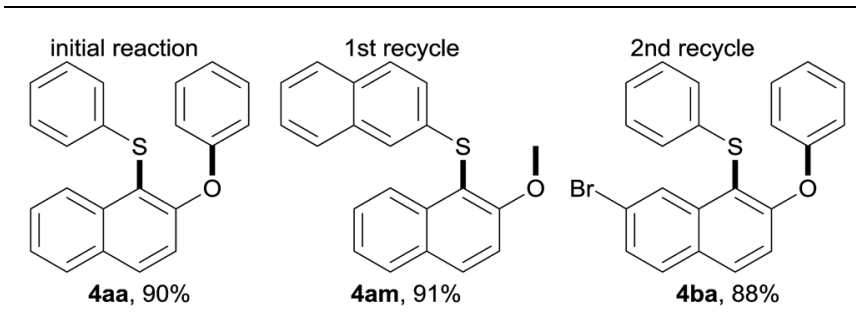

\begin{tabular}{llll}
\hline & \multicolumn{3}{c}{ E Factors } \\
\cline { 2 - 4 } Based on & Reaction & 1st recycle & 2nd recycle \\
\hline Total organic solvent & 4.0 & 4.2 & 3.4 \\
Aqueous waste included & 8.6 & 4.2 & 3.4
\end{tabular}

${ }^{a}$ Conditions: 3 (0.375 mmol), $\mathrm{K}_{3} \mathrm{PO}_{4}$ (1.125 mmol), 2 wt\% TPGS-750-M/ $\mathrm{H}_{2} \mathrm{O}(0.75 \mathrm{M})$ at $70{ }^{\circ} \mathrm{C}$ for $24 \mathrm{~h} .{ }^{b}$ Isolated yields.

\section{Conclusions}

In conclusion, we have developed an unprecedented approach for $\mathrm{C}-\mathrm{H} / \mathrm{O}-\mathrm{H}$ difunctionalization of phenols under mild conditions. The process is mediated by an electrophilic aromatic substitution and subsequent Smiles-like rearrangement, involving $\mathrm{C}-\mathrm{S}$ and $\mathrm{C}-\mathrm{O}$ bond formations. Notably, this rearrangement proceeded under aqueous micellar conditions, successfully addressing several environmental issues. Further studies on related rearrangements featuring multiple bond-formations in water are currently in progress in our laboratories.

\section{Acknowledgements}

Financial support provided by the National Key Research and Development Program (2016YFD0600801), the Natural Science Foundation of China (21502094), the Jiangsu SpeciallyAppointed Professor Plan, and the Priority Academic Program Development of Jiangsu Higher Education Institutions (PAPD) is warmly acknowledged with thanks.

\section{Notes and references}

1 (a) Metal-Catalyzed Cross-Coupling Reactions, ed. A. de Meijere, and F. Diederich, Wiley-VCH, Weinheim, 2004; (b) Handbook of Organopalladium Chemistry for Organic Synthesis, ed. E.-I. Negishi, Wiley-Interscience, New York, 2002; (c) Cross-Coupling Reactions: A Practical Guide, Topics in Current Chemistry Series 219, ed. N. Miyaura, Springer, New York, 2002; (d) Catalyzed Carbon-Heteroatom Bond Formation, ed. A. K. Yudin, Wiley-VCH, Weinheim, 2011; (e) J. Yin, in Applications of Transition Metal Catalysis in Drug Discovery and Development, ed. M. L. Crawley and B. M. Trost, John Wiley and Sons, Hoboken, 2012, pp. 97-163.

2 For selected reviews and examples, see: (a) I. P. Beletskaya and V. P. Ananikov, Chem. Rev., 2011, 111, 1596; (b)
P. Bichler and J. A. Love, Top. Organomet. Chem., 2010, 31, 39; (c) J. F. Hartwig, Acc. Chem. Res., 2008, 41, 1534; (d) M. Murata and S. L. Buchwald, Tetrahedron, 2004, 60, 7397; (e) M. A. Fernández-Rodríguez, Q. Shen and J. F. Hartwig, J. Am. Chem. Soc., 2006, 128, 2180; (f) K. W. Anderson, T. Ikawa, R. E. Tundel and S. L. Buchwald, J. Am. Chem. Soc., 2006, 128, 10694; ( $g$ ) S. Gowrisankar, A. G. Sergeev, P. Anbarasan, A. Spannenberg, H. Neumann and M. Beller, J. Am. Chem. Soc., 2010, 132, 11592; $(h)$ G. Bastug and S. P. Nolan, J. Org. Chem., 2013, 78, 9303; (i) C. Uyeda, Y. Tan, G. C. Fu and J. C. Peters, J. Am. Chem. Soc., 2013, 135, 9548; (j) Y. Tan, J. M. Muñoz-Molina, G. C. Fu and J. C. Peters, Chem. Sci., 2014, 5, 2831; (k) J. Mao, T. Jia, G. Frensch and P. J. Walsh, Org. Lett., 2014, 16, 5304; (l) Z. Qiao, J. Wei and X. Jiang, Org. Lett., 2014, 16, 1212; (m) M. W. Johnson, K. I. Hannoun, Y. Tan, G. C. Fu and J. C. Peters, Chem. Sci., 2016, 7, 4091; (n) F.-G. Sun, M. Li, C.-F. He, B. Wang, B. Li, X.-W. Sui and Z.-H. Gu, J. Am. Chem. Soc., 2016, 138, 7456.

3 (a) M. Mellah, A. Voituriez and E. Schulz, Chem. Rev., 2007, 107, 5133; (b) D. A. Evans, K. R. Campos, J. S. Tedrow, F. E. Michael and M. R. Gagne, J. Am. Chem. Soc., 2000, 122, 7905; (c) D. A. Evans, F. E. Michael, J. S. Tedrow and K. R. Campos, J. Am. Chem. Soc., 2003, 125, 3534; (d) D.-H. Bao, H.-L. Wu, C.-L. Liu, J.-H. Xie and Q.-L. Zhou, Angew. Chem., Int. Ed., 2015, 54, 8791; (e) Y. Wei, L.-Q. Lu, T.-R. Li, B. Feng, Q. Wang, W.-J. Xiao and H. Alper, Angew. Chem., Int. Ed., 2016, 55, 2200; (f) L. A. Damani, SulphurContaining Drugs and Related Organic Compounds, Wiley, 1989; (g) E. A. Ilardi, E. Vitaku and J. T. Njardarson, J. Med. Chem., 2014, 57, 2832.

4 (a) T. Laird, Org. ProcessRes. Dev., 2012, 16, 1; (b) P. J. Dunn, Pharmaceutical Process Development, ed. J. A. Blacker and M. T. Williams, Royal Society of Chemistry, London, 2011, ch. 6; (c) C. Jimenez-Gonzales and D. J. Constable, Green Chemistry and Engineering: A Practical Approach, Wiley, New York, 2011; (d) R. A. Sheldon, I. W. C. E. Arends and U. Hanefeld, Green Chemistry and Catalysis, Wiley-VCH, Weinheim, 2007.

5 (a) T. Hostier, V. Ferey, G. Ricci, P. D. Gomez and J. Cossy, Org. Lett., 2015, 17, 3898; (b) A. M. Wagner and M. S. Sanford, J. Org. Chem., 2014, 79, 2263; (c) F.-L. Yang and S.-K. Tian, Angew. Chem., Int. Ed., 2013, 52, 4929; (d) A. S. Henderson, S. Medina, J. F. Bower and M. C. Galan, Org. Lett., 2015, 17, 4846; (e) Y.-Y. Dong, M. I. Lipschutz and T. D. Tilley, Org. Lett., 2016, 18, 1530.

6 (a) C. E. Garrett and K. Prasad, Adv. Synth. Catal., 2004, 346, 889; (b) V. W. Rosso, D. A. Lust, P. J. Bernot, J. A. Grosso, S. P. Modi, A. Rusowicz, T. C. Sedergran, J. H. Simpson, S. K. Srivastava, M. J. Humora and N. G. Anderson, Org. Process Res. Dev., 1997, 1, 311.

7 For selected reviews and examples, see: (a) A. Shafir, Tetrahedron Lett., 2016, 57, 2673; (b) A. P. Pulis and D. J. Procter, Angew. Chem., Int. Ed., 2016, 55, 9842; (c) L. H. S. Smith, S. C. Coote, H. F. Sneddon and D. J. Procter, Angew. Chem., Int. Ed., 2010, 49, 5832; (d) S. K. Bur and A. Padwa, Chem. Rev., 2004, 104, 2401; (e) J. A. Fernández-Salas, A. J. Eberhart and D. J. Procter, J. Am. 
Chem. Soc., 2016, 138, 790; $(f)$ J. A. Fernández-Salas, A. P. Pulis and D. J. Procter, Chem. Commun., 2016, 52, 12364. 8 (a) J. F. Burnett and R. E. Zalher, Chem. Rev., 1951, 49, 273; (b) W. E. Truce, E. M. Kreider and W. W. Brand, Org. React., 1970, 18, 99.

9 (a) G. Sipos, E. E. Drinkel and R. Dorta, Chem. Soc. Rev., 2015, 44, 3834, and references cited therein; (b) Y. Tang, Y. Sun, J. Liu and S. Duttwyler, Org. Biomol. Chem., 2016, 14, 5580.

10 (a) A. G. Geyer, W. J. McClellan, T. W. Rochway, K. D. Stewart, M. Weitzberg and M. D. Wendt, US Pat. 6,258,822, 2001; (b) A. G. Geyer, W. J. McClellan, T. W. Rochway, K. D. Stewart, M. Weitzberg and M. D. Wendt, US Pat. 6,284,796, 2001; (c) T. Nakazawa, J. Xu, T. Nishikawa, T. Oda, A. Fujita, K. Ukai, R. E. P. Mangindaan, H. Rotinsulu, H. Kobayashi and M. Namikoshi, J. Nat. Prod., 2007, 70, 439; (d) M. P. Crump, T. A. Ceska, L. Spyracopoulos, A. Henry, S. C. Archibald, R. Alexander, R. J. Taylor, S. C. Findlow, J. O'Connell, M. K. Robinson and A. Shock, Biochemistry, 2004, 43, 2394; (e) B. Wang, L. Li, T. D. Hurley and S. O. Meroueh, J. Chem. Inf. Model., 2013, 53, 2659; (f) T. A. Blizzard, F. DiNinno, J. D. Morgan II, H. Y. Chen, J. Y. Wu, S. Kim, W. Chan, E. T. Birzin, Y. T. Yang, L.-Y. Pai, P. M. D. Fitzgerald, N. Sharma, Y. Li, Z. Zhang, E. C. Hayes, C. A. DaSilva, W. Tang, S. P. Rohrer, J. M. Schaeffer and M. L. Hammond, Bioorg. Med. Chem. Lett., 2005, 15, 107; $(g)$ T. A. Blizzard, F. DiNinno, H. Y. Chen, S. Kim, J. Y. Wu, W. Chan, E. T. Birzin, Y. T. Yang, L.-Y. Pai, E. C. Hayes, C. A. DaSilva, S. P. Rohrer, J. M. Schaeffer and M. L. Hammond, Bioorg. Med. Chem. Lett., 2005, 15, 3912; (h) T. A. Blizzard, F. DiNinno, H. Y. Chen, S. Kim, J. Y. Wu, W. Chan, E. T. Birzin, Y. T. Yang, L.-Y. Pai, E. C. Hayes, C. A. DaSilva, S. P. Rohrer, J. M. Schaeffer and
M. L. Hammond, Bioorg. Med. Chem. Lett., 2005, 15, 5124; (i) S. Zhuang, J. Zhang, F. Zhang, Z. Zhang, Y. Wena and W. Liu, Bioorg. Med. Chem. Lett., 2011, 21, 7298; (j) L. D. B. Salum, I. Polikarpov and A. D. Andricopulo, J. Mol. Graphics Modell., 2007, 26, 434; (k) S. Park, I. Kufareva and R. Abagyan, J. Comput.-Aided Mol. Des., 2010, 24, 459; (l) L. Gao, Y. Tu and L. A. Eriksson, J. Biophys. Chem., 2011, 2, 233; $(m)$ F. P. DiNinno, T. A. Blizzard and J. D. Morgan II, US Pat. 0,234,245, 2005.

11 (a) K. Murakami, H. Yorimitsu and A. Osuka, Angew. Chem., Int. Ed., 2014, 53, 7510; (b) X. Huang, M. Patil, C. Farès, W. Thiel and N. Maulide, J. Am. Chem. Soc., 2013, 135, 7312; (c) X. Huang and N. Maulide, J. Am. Chem. Soc., 2011, 133, 8510; (d) Y. Ookubo, A. Wakamiya, H. Yorimitsu and A. Osuka, Chem.-Eur. J., 2012, 18, 12690; (e) T. Kobatake, D. Fujino, S. Yoshida, H. Yorimitsu and K. Oshima, J. Am. Chem. Soc., 2010, 132, 11838; (f) T. Kobatake, S. Yoshida, H. Yorimitsu and K. Oshima, Angew. Chem., Int. Ed., 2010, 49, 2340.

12 (a) X. Huang, R. Goddard and N. Maulide, Angew. Chem., Int. Ed., 2010, 49, 8979; (b) M. N. Kim and K. Kim, J. Heterocycl. Chem., 1998, 35, 235.

13 B. H. Lipshutz and S. Ghorai, Green Chem., 2014, 16, 3660, and references cited therein.

14 (a) B. H. Lipshutz, S. Ghorai, A. R. Abela, R. Moser, T. Nishikata, C. Duplais, A. Krasovskiy, R. D. Gaston and R. C. Gadwood, J. Org. Chem., 2011, 76, 4379-4391; (b) Aldrich catalog number 763918.

15 (a) B. H. Lipshutz, N. A. Isley, J. C. Fennewald and E. D. Slack, Angew. Chem., Int. Ed., 2013, 52, 10952, and references cited therein; (b) F. Roschangar, R. A. Sheldon and C. H. Senanayake, Green Chem., 2015, 17, 752. 